\title{
C1QA wt Allele
}

National Cancer Institute

\section{Source}

National Cancer Institute. C1QA wt Allele. NCI Thesaurus. Code C105380.

Human C1QA wild-type allele is located in the vicinity of 1 p36.12 and is approximately $3 \mathrm{~kb}$ in length. This allele, which encodes complement C1q subcomponent subunit A protein, is involved in the initiation of complement-mediated immunity. Mutation of the gene is associated with complement component C1q deficiency. 